\begin{tabular}{|c|c|}
\hline \multirow{3}{*}{ 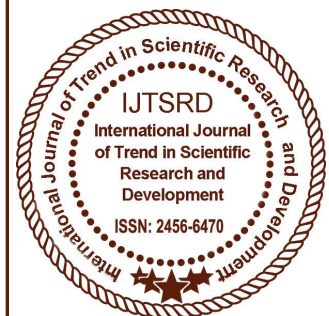 } & $\begin{array}{l}\text { International Journal of Trend in Scientific } \\
\text { Research and Development (IJTSRD) }\end{array}$ \\
\hline & International Open Access Journal \\
\hline & ISSN No: 2456 - 6470 | www.ijtsrd.com | Volume - 2 | Issue -4 \\
\hline
\end{tabular}

\title{
Assessment of Water Quality of Himayath Sagar and Osman Sagar Based on Biological Oxygen Demand
}

\author{
Mrs. Juvaria Azmath \\ Lecturer, St. Ann's College for Women, \\ Mehdipatnam, Hyderabad, India
}

\begin{abstract}
The present study was carried out to assess the water quality of Himayath Sagar and Osman Sagar based on Biological Oxygen Demand. For this study systemic sampling has been carried out by collecting 10 water samples from each lake. The collected samples were analysed for Biological Oxygen Demand using Biological Oxygen Demand Indicator(BOD indicator). The results were compared with water quality guidelines for drinking as well as fishing. The mean values for both the lakes were higher than acceptable limits.
\end{abstract}

Keywords: Bioloical Oxygen Demand; dissolved oxygen; bacteria; water quality; pollution; water

\section{INTRODUCTION}

Biochemical oxygen demand is a quantitative expression of microbes ability to deplete the oxygen content of water. This depletion takes place due to the microbes consuming organic matter in the water via aerobic respiration. Aquatic organisms use dissolved oxygen to survive. If the dissolved oxygen drops to below a critical level the ecology of the streamn will be damaged. The decrease in the oxygen supply in the water has a negative effect on the aquatic life. This can lead to an increase in anaerobic bacteria that leads to the production of foul-smelling, and possibly toxic gases. These gases may include methane, hydrogen sulfide, and ammonia. If this water is consumed, there are bound to be many potential problems of toxicity to humans. Biological Oxygen Demand (BOD) is one of the most common measures of pollutant organic material in water. BOD indicates the amount of pollutants present in water. Therefore, a low BOD is an indicator of good quality water, while a high BOD indicates polluted water.

The BOD test serves an important function in stream pollution-control activities. It is a bioassay procedure that measures the amount of oxygen consumed by living organisms while they are utilizing the organic matter present in waste.

Methods and Methodology:

10 water samples were taken from both Himayath sagar lake and Osman Sagar lake in Hyderabad. Each sample was tested for Biological Oxygen Demand. For determining the Biological Oxygen Demand, BOD indicator has been used. The experiment was performed based on standard method for calculation of oxygen content in water .BOD is calculated by keeping the water in BOD incubator for 5 days. Dissolved oxygen is calculated both before and after keeping in BOD indicator. BOD incubator is the most versatile and reliable low temperature incubator which maintain a constant temperature of $20^{\circ} \mathrm{C}$. The BOD is calculated from the difference between initial and final Dissolved oxygen values.

\section{Formula :}

$\mathrm{N} 1 \mathrm{~V} 1=\mathrm{N} 2 \mathrm{~V} 2$

Where N1=Normality of oxygen

$\mathrm{V} 1=$ Volume of sample

N2=Normality of Hypo or Sodium thio sulphate

V2=Volume of Hypo or Sodium thio sulphate 
Amount of oxygen in ppm $=\mathrm{N} 1 \times 8 \times 1000$

$\mathrm{BOD}=\mathrm{D} 1-\mathrm{D} 2$

D1=Initial dissolved oxygen

D2=Final dissolved oxygen .

Result:

The BOD value of Osman Sagar water was found to be 4 ppm and the BOD value of Himayath Sagar was found to be 3.2. The normal BOD value for drinking water should be less tha 3 according to BIS(Bureau of Indian Standards)

\section{Conclusion:}

The BOD values of Osman Sagar and Himayathsagar were found to be more than the normal BOD value for drinking water. The Lakes are being polluted by Human Intervention. As the BOD levels are more fishes and other aquatic organisms may not survive.

\section{References}

1. Ecology by P. D. harma

2. https://www.researchgate.net/file.PostFileLoader. html?id... assetKe

3. https://en.wikipedia.org/wiki/Hyderabad_city_lak es 